University of New Hampshire

University of New Hampshire Scholars' Repository

Faculty Publications

$11-1-1998$

\title{
EFFECTS OF LAND COVER, WATER REDISTRIBUTION, AND TEMPERATURE ON ECOSYSTEM PROCESSES IN THE SOUTH PLATTE BASIN
}

\author{
Jill S. Baron \\ U.S. Geological Survey \\ Melannie D. Hartman \\ Colorado State University \\ Timothy G. F. Kittel \\ National Center for Atmospheric Research \\ Larry E. Band \\ University of North Carolina \\ Dennis S. Ojima \\ Colorado State University
}

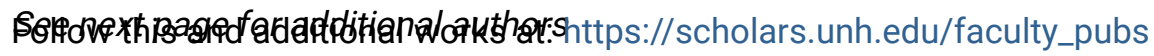

Comments

This is an article published by Ecological Society of America (ESA) in Ecological Applications in 1998, available online: https://dx.doi.org/10.1890/1051-0761(1998)008[1037:EOLCWR]2.0.CO;2

\section{Recommended Citation}

Baron, J.S., M.D. Hartman, T.G.F. Kittel, L.E. Band, D.S. Ojima and R.B. Lammers (1998) Effects of Land Cover, Water Redistribution, and Temperature on Ecosystem Processes in the South Platte Basin, Ecological Applications, 8(4):1037-1051.

This Article is brought to you for free and open access by University of New Hampshire Scholars' Repository. It has been accepted for inclusion in Faculty Publications by an authorized administrator of University of New Hampshire Scholars' Repository. For more information, please contact Scholarly.Communication@unh.edu. 


\section{Authors}

Jill S. Baron, Melannie D. Hartman, Timothy G. F. Kittel, Larry E. Band, Dennis S. Ojima, and Richard B. Lammers 


\title{
EFFECTS OF LAND COVER, WATER REDISTRIBUTION, AND TEMPERATURE ON ECOSYSTEM PROCESSES IN THE SOUTH PLATTE BASIN
}

\author{
J. S. Baron, ${ }^{1,2}$ M. D. Hartman, ${ }^{2}$ T. G. F. Kittel, ${ }^{3}$ L. E. Band, ${ }^{4,6}$ D. S. Ojima, ${ }^{2}$ And R. B. Lammers \\ ${ }^{1}$ Mid-Continent Ecological Science Center, U.S. Geological Survey Biological Resources Division, \\ Fort Collins, Colorado 80523 USA \\ ${ }^{2}$ Natural Resource Ecology Laboratory, Colorado State University, Fort Collins, Colorado 80523 USA \\ ${ }^{3}$ National Center for Atmospheric Research, Box 3000, Boulder, Colorado 80307 USA \\ ${ }^{4}$ Department of Geography, University of Toronto, Toronto, Ontario, Canada M5S 1AI \\ ${ }^{5}$ Complex System Research Center, University of New Hampshire, Durham, New Hampshire 03824 USA
}

Abstract. Over one-third of the land area in the South Platte Basin of Colorado, Nebraska, and Wyoming, has been converted to croplands. Irrigated cropland now comprises $8 \%$ of the basin, while dry croplands make up $31 \%$. We used the RHESSys model to compare the changes in plant productivity and vegetation-related hydrological processes that occurred as a result of either land cover alteration or directional temperature changes $\left(-2^{\circ} \mathrm{C},+4^{\circ} \mathrm{C}\right)$. Land cover change exerted more control over annual plant productivity and water fluxes for converted grasslands, while the effect of temperature changes on productivity and water fluxes was stronger in the mountain vegetation. Throughout the basin, land cover change increased the annual loss of water to the atmosphere by $114 \mathrm{~mm}$ via evaporation and transpiration, an increase of $37 \%$. Both irrigated and nonirrigated grains became active earlier in the year than shortgrass steppe, leading to a seasonal shift in water losses to the atmosphere. Basin-wide photosynthesis increased by $80 \%$ due to grain production. In contrast, a $4^{\circ} \mathrm{C}$ warming scenario caused annual transpiration to increase by only $3 \%$ and annual evaporation to increase by $28 \%$, for a total increase of $71 \mathrm{~mm}$. Warming decreased basin-wide photosynthesis by $16 \%$. There is a large elevational range from east to west in the South Platte Basin, which encompasses the western edge of the Great Plains and the eastern front of the Rocky Mountains. This elevational gain is accompanied by great changes in topographic complexity, vegetation type, and climate. Shortgrass steppe and crops found at elevations between 850 and $1800 \mathrm{~m}$ give way to coniferous forests and tundra between 1800 and $4000 \mathrm{~m}$. Climate is increasingly dominated by winter snow precipitation with increasing elevation, and the timing of snowmelt influences tundra and forest ecosystem productivity, soil moisture, and downstream discharge. Mean annual precipitation of $<500 \mathrm{~mm}$ on the plains below $1800 \mathrm{~m}$ is far less than potential evapotranspiration of 1000-1500 $\mathrm{mm}$ and is insufficient for optimum plant productivity. The changes in water flux and photosynthesis from conversion of steppe to cropland are the result of redistribution of snowmelt water from the mountains and groundwater pumping through irrigation projects.

Key words: climate change; Colorado; ecosystem dynamics; hydrology; land cover change; land use change; RHESSys model; South Platte River; water redistribution.

\section{INTRODUCTION}

The interface between the Great Plains and the Rocky Mountains in Colorado is a complex region where large areas of shortgrass steppe have been converted to dryland and irrigated croplands. In addition, there has been a 30-yr trend of increasing temperatures throughout the Great Plains and the western United States, in keeping with general circulation model scenarios of increasing atmospheric $\mathrm{CO}_{2}$ concentrations

Manuscript received 28 July 1997; revised 14 January 1998; accepted 3 February 1998; final version received 6 March 1998.

${ }^{6}$ Present address: Department of Geography, 203 Saunders Hall, University of North Carolina, Chapel Hill, North Carolina 27599 USA.
(Lauenroth and Sala 1992, Karl et al. 1993, Watson et al. 1996). Both land cover change and globally forced climate alterations influence regional ecosystem processes, although not necessarily in the same way or with the same magnitude. Direct and indirect effects of both may combine in unexpected ways.

\section{Effects of climate change}

Temperature changes can affect regional vegetation productivity and hydrology by enhancing or reducing evapotranspiration (ET) and by lengthening or shortening the growing season. Where there is ample precipitation and soil moisture available during the growing season, an increase in ET from warming will not impair, and may enhance, primary production. At high 
elevations in the mountains, tundra and coniferous forest growth are limited by temperature, not moisture (Peet 1989), so warming is expected to enhance net primary productivity. In the Great Plains, however, annual potential evapotranspiration (PET) is $>1000 \mathrm{~mm}$ and exceeds the mean annual precipitation of $<500 \mathrm{~mm}$ (Sims 1989). Warming is expected to increase the ratio of ET to precipitation unless there are substantial concurrent increases in annual precipitation. Between the plains and the subalpine forest belt there is a midelevation transition zone of montane conifers at 1800 $2500 \mathrm{~m}$, where complex topography influences exposure and microclimate, and soil moisture is strongly controlled by aspect and soil texture. In this elevational region, growth is enhanced or reduced with warming, depending on location (Stohlgren and Bachand 1997).

In the shortgrass steppe, additional precipitation would enhance plant production, and long-term net primary productivity records confirm that wet years are more productive than dry years (Sala et al. 1988). Because PET rises with air temperature, however, areas with increased precipitation may still experience a reduction in water supplies with warming if ET exhausts available water (Watson et al. 1996).

Precipitation to the central Rocky Mountains comes primarily as winter snow, and mountain river runoff is dominated by snowmelt (Baron 1992, Rango 1995). Climate warming in temperate mountainous regions is projected to have a greater influence on the timing of snowmelt than on the volume of snowmelt runoff (Rango 1995, Baron et al. 1998). Simulations of Rocky Mountain hydrologic responses suggested that discharge will decrease somewhat $(\sim 5 \%)$ with increased temperatures, except in small glacierized basins where discharge is projected to increase slightly (Rango 1995, Baron et al. 1998). In contrast to the dampened response to temperature, discharge responds almost linearly to changes in winter precipitation (Nash and Gleick 1993, Rango 1995, Baron et al. 1998). In this respect, high-elevation catchments operate differently from lower elevation and more temperate watersheds, where forest ET competes with stream flow (Sala et al. 1988, Likens and Borman 1995, Schindler 1997). Many Rocky Mountain watersheds have their headwaters (and the bulk of their snowpack) in alpine tundra or talus fields, where melt begins before ET becomes important. Because of this, plant water requirements are somewhat uncoupled from stream flow.

\section{Effects of land and water use changes}

Land use change in the short grass steppe exerts a strong negative influence on ecosystem carbon balance at all elevations, through harvest, loss of soil organic matter, and erosion (Burke et al. 1991). Land cover alterations in the mountains, such as those brought about by logging, can cause short-term increases in stream discharge through re-allocation of soil water from transpiration to runoff and through lowered evap- orative surface area (Goudie 1990). Irrigated agriculture and urbanization are major land uses that spatially redistribute water resources from river channels to fields and reservoirs. In the South Platte River Basin, $\sim 80 \%$ of the annual surface water supply is used within the basin for urban and agricultural needs (Dennehy et al. 1993). A large volume of ground water is also extracted from aquifers of the South Platte Basin and applied to irrigation. South Platte aquifers are regularly replenished from mountain snowmelt, and thus differ from groundwater aquifers whose waters are Pleistocene remnants.

Subtle ecologic and hydrologic changes may occur through changes in regional climate driven by land use and land cover. Changes in vegetation canopy characteristics such as leaf area, albedo, evapotranspiration rates, and roughness can influence regional and global climate, as suggested both by observations (Barnston and Schickedanz 1984, Meher-Homji 1991) and model simulations (Shukla and Mintz 1982, Shukla et al. 1990, Chase et al. 1996, Zhang et al. 1996). Using a climate version of the mesoscale atmospheric model, RAMS, Copeland and colleagues suggested that significant changes in temperature, humidity, wind speed, and precipitation may have occurred in Colorado due to land use change (Copeland et al. 1996, Pielke et al. 1992). Short-term (three-day) and fine-grid (6.5-km) RAMS simulations for the Colorado Front Range under scenarios of pre-European settlement shortgrass steppe vs. current land use also showed substantial differences in precipitation, temperature, and cloud cover from land use change alone (Chase et al. 1998, Stohlgren et al. 1998).

Understanding the effects of land use, water redistribution, and climate change is important in developing a better appreciation of the ecologic, social, and economic limits on the region. While there is a body of literature addressing direct ecologic and hydrologic responses to climate and land use, not nearly enough is known about more subtle consequences, such as the feedbacks between land surface processes and climate variability (Lubchenko et al. 1991, Pielke et al. 1997, Steyaert et al. 1997). Using RHESSys, the Regional Hydro-Ecological Simulation System (Band et al. 1993), we asked how sensitive regional ecosystem dynamics are to both land cover change and climate alteration. We compared fluxes of carbon and water from the South Platte River Basin under potential natural vegetation, under current land cover, and in response to changes in temperature.

\section{Study region}

Headwaters of the $62900-\mathrm{km}^{2}$ South Platte River begin at $4000 \mathrm{~m}$ elevation along the Continental Divide and flow $720 \mathrm{~km}$ to its confluence with the North Platte River in Nebraska (Fig. 1). Seventy percent of Colorado's population, more than two million people, live in the basin (Dennehy et al. 1993). Precipitation in the 


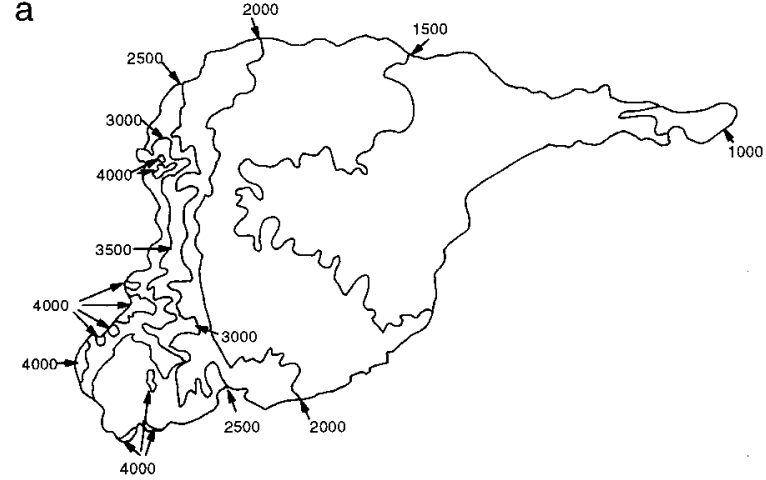

b

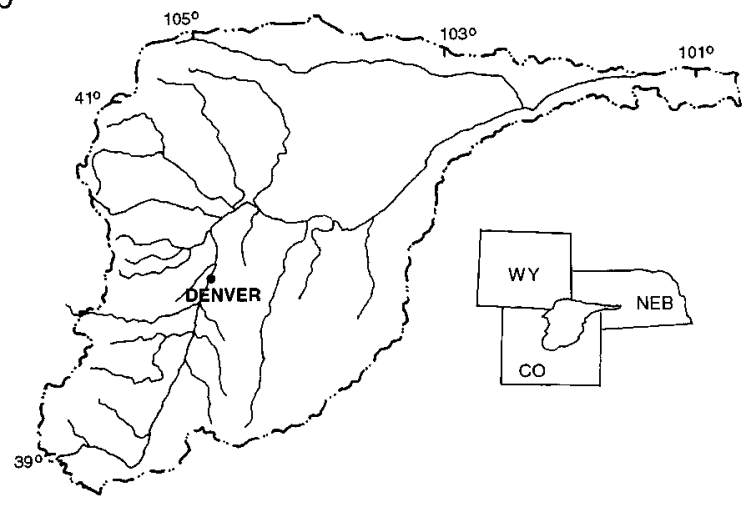

FIG. 1. South Platte River Basin of Colorado, Wyoming, and Nebraska. (a) Digital elevation map (redrawn from EROS Data Center DEM, Sioux Falls, South Dakota); (b) hydrologic and political features (redrawn from Dennehy 1993).

mountains is $>1000 \mathrm{~mm}$ annually, compared with 300 $400 \mathrm{~mm}$ on the plains (Fig. 2). Because PET for the plains is greater than precipitation, water often limits primary productivity, and there is rarely subsurface runoff, except for return flow from irrigated croplands (Sala et al. 1988, Sims 1989). Currently, precipitation supplies $24680 \times 10^{6} \mathrm{~m}^{3} / \mathrm{yr}$ to the South Platte River Basin (Dennehy et al. 1993). Imported water, mostly from the Colorado and Arkansas River basins, adds an additional $494 \times 10^{6} \mathrm{~m}^{3} / \mathrm{yr}$ (Dennehy et al. 1993). While a water budget for the South Platte Basin is beyond the scope of this paper, this amounts to a substantial seasonal and spatial redistribution of water resources.

\section{Methods and Data Layers}

\section{Methods}

RHESSys is a spatial data and simulation system that uses geographic information system techniques to transform spatial data into a landform description, and has a set of process models, FOREST-BGC and TOPMODEL, that compute water and carbon flux through watersheds (Band et al. 1993). FOREST-BGC is a stand-level model of forest carbon and water budgets that has been parameterized for use in both forested a) Loch Vale (1983-1992)
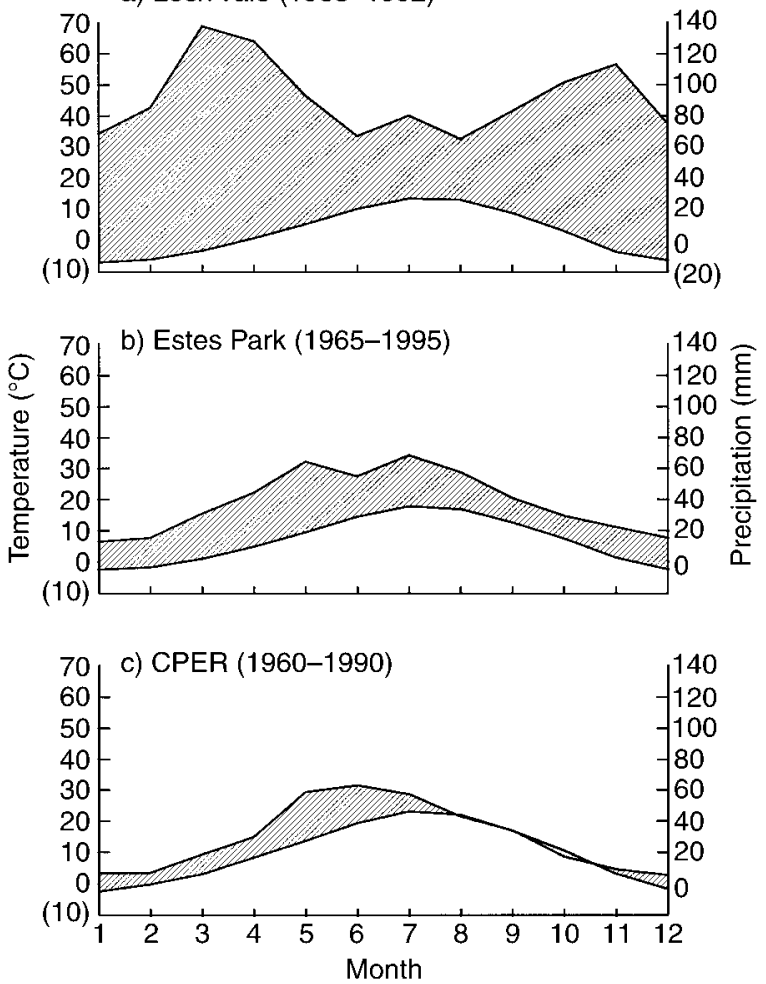

FIG. 2. Climate diagrams for three elevations within the South Platte River basin: (a) Loch Vale Watershed (3146 m); (b) Estes Park (2295 m); and (c) Central Plains Experimental Range (CPER, $1650 \mathrm{~m}$ ), showing years of record from which each graph was derived. Hatched areas represent relative humidity season when actual evapotranspiration is less than potential. Mean annual temperature and precipitation are (a) $2.5^{\circ} \mathrm{C}, 1099 \mathrm{~mm}$; (b) $6.3^{\circ} \mathrm{C}, 432 \mathrm{~mm}$; and (c) $9.2^{\circ} \mathrm{C}, 334 \mathrm{~mm}$, respectively. Data are from (a) Loch Vale database (Baron 1992), (b) Colorado Climate Data (1992), and (c) Shortgrass Steppe Long-Term Ecological Research (1996).

and grassland landscapes (Running and Coughlan 1988, Hunt et al. 1996). In this version of FOREST$\mathrm{BGC}, \mathrm{C}_{3}$ and $\mathrm{C}_{4}$ physiological processes were not delineated. FOREST-BGC is coupled with TOPMODEL, a quasi-distributed hydrological model (Beven and Kirkby 1979) to model watershed hydro-ecological processes (Band et al. 1993). Daily weather (temperature maxima and minima, precipitation) was extrapolated to each hillslope with MTCLIM-3D (Thornton et al. 1997). RHESSys has been applied to hydrological investigations, forest productivity, regional-scale water and carbon budgets, climate change scenarios, and nitrogen leaching (Running et al. 1989, Band et al. 1991, 1993, 1996, Running and Nemani 1991, Band 1993, 1994, Creed et al. 1996). RHESSys offers spatially distributed daily output. The model is fully described in Band et al. (1993), and modifications are described below.

To better represent steep mountain watersheds, we modified the original spatial framework described in Band et al. (1993) to resolve temperature and precip- 
TABle 1. Land cover types in the South Platte River Basin.

\begin{tabular}{lccccr}
\hline \hline & \multicolumn{2}{c}{ Potential vegetation } & & \multicolumn{2}{c}{ Current vegetation } \\
\cline { 2 - 3 } \cline { 5 - 6 } Cover type & Area $\left(\mathrm{km}^{2}\right)$ & $(\%)$ & & Area $\left(\mathrm{km}^{2}\right)$ & $(\%)$ \\
\hline Alpine & 2031 & 3.3 & & 1948 & 3.2 \\
Coniferous & 11296 & 18.3 & & 8956 & 14.5 \\
Deciduous & 1040 & 1.7 & & 732 & 1.2 \\
Shortgrass & 47211 & 76.7 & & 25983 & 42.2 \\
Dry crops $\dagger$ & $\ldots$ & $\ldots$ & & 18941 & 30.8 \\
Wet crops & $\ldots$ & $\ldots$ & & 5018 & 8.1 \\
Total & 61578 & 100.0 & & 61578 & 100.0 \\
\hline
\end{tabular}

$\dagger$ During the growing season, land area listed as dry crops is split evenly between cropland and fallow land.

itation gradients on each hillslope and a snow redistribution option to imitate wind redistribution of snowpack (Lammers et al. 1997; M. D. Hartman, C. Tague, L. E. Band, J. S. Baron, R. L. Lammers, and D. W. Cline, unpublished manuscript). The micrometeorology model, MTCLIM-3D, extrapolated base station meteorology to each 200-m elevation band for each hillslope. This allowed temperature and precipitation to vary on hillslopes with wide topographic gradients.

Canopy interception of rain, hence the amount of moisture routed to evaporation rather than to soils for transpiration, is directly proportional to LAI (leaf area index, the total [two-sided] leaf area per unit area of ground). This results in high model sensitivity to changes in LAI. For example, an increase of LAI from 2 to 6 when native grasses are converted to crops increases interception from $\sim 30$ to $100 \%$ for precipitation events of $<2 \mathrm{~mm}$.

Soils were kept wet for irrigated crops during the growing season (15 April-15 August) by adding water daily at twice the PET rate. Irrigation water was added directly to the top of the soil, so that it entered soil via the soil litter layer.

\section{Data layers}

Elevation was derived from the $1 \mathrm{~km}$ resolution U.S. conterminous digital elevation model (DEM) accompanying the EROS Data Center 1-km AVHRR/NDVI data set (Eidenshink 1992). The South Platte Basin was divided into 136 individual hillslopes with a terrainpartitioning algorithm (Band et al. 1993). This is done by extracting a drainage network from the DEM, wherein nested subcatchments are delineated based on stream links. Stream links are the unbranched reaches of stream channels between stream junctions or the source. The terrestrial part of each subcatchment is partitioned into areas that contribute drainage waters to each side of a stream link (Band et al. 1996). Hillslopes were necessarily coarse at the scale of the entire South Platte Basin, and each hillslope contained more than one well-defined catchment, especially in mountainous areas of high topographic relief. Slope, aspect, and the wetness index were calculated by digital terrain analysis from the digital elevation data layer. Saturated
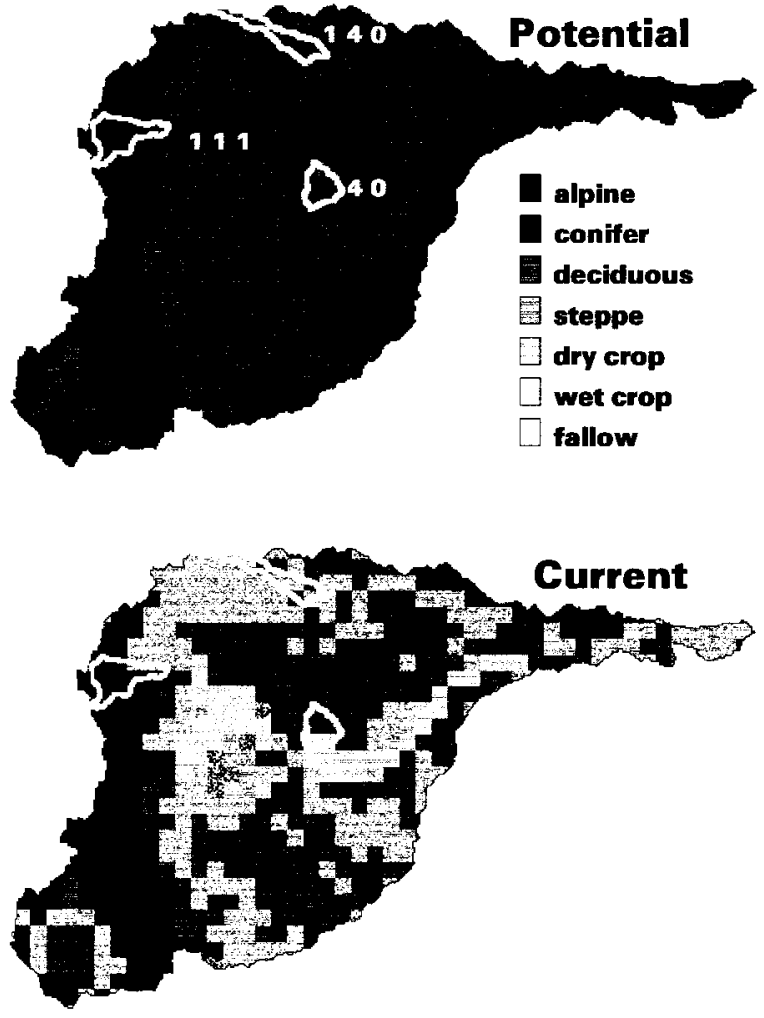

FIG. 3. Land cover classifications for the South Platte River basin. The top panel shows potential vegetation (derived from Küchler [1975]); the bottom panel shows current vegetation (Loveland et al. 1991). Grid size is $10 \mathrm{~km}$. Stippled areas of current classification represent mixed vegetation types within a grid: dry crop and fallow, or wet crop and deciduous. The three hillslopes discussed in the text are outlined: Hillslope 111 is mostly alpine and coniferous forest; Hillslope 140 was converted from steppe to mostly dry crop and fallow; and Hillslope 40 was converted from steppe to mostly wet crop (refer to Table 5).

hydraulic conductivity $\left(K_{\mathrm{o}}\right)$ was derived as a linear function of the wetness index $(W)$ :

$$
K_{\mathrm{o}}=100-5 \mathrm{~W} .
$$

This equation provides for a gradation in soils from coarser to finer moving downslope. The hydraulic conductivity generated gave a mean value of $67 \mathrm{~cm} / \mathrm{d}$, with a standard deviation of $8.9 \mathrm{~cm} / \mathrm{d}$ (Lammers 1998).

Potential land cover was derived from Küchler's natural vegetation map to represent pre-agricultural conditions (Küchler 1975, VEMAP Members 1995, Kittel et al. 1995). This map was initially developed with 10$\mathrm{km}$ resolution; each vegetation grid was divided into 100 equal 1-km pixels for our simulations. Current land cover was obtained from the EROS Data Center (EDC) 1-km AVHRR data base for the conterminous United States (Loveland et al. 1991), with the following modification: for cells where the Loveland et al. (1991) current land cover map indicated natural vegetation, the natural vegetation type from Küchler (1975) was used to provide consistency between the two maps ( $\mathrm{T}$. 
TABLE 2. Leaf area index (LAI) and phenology of land cover types simulated for the South Platte Basin.

\begin{tabular}{|c|c|c|c|}
\hline Vegetation & Min. LAI & Max. LAI & Phenology $\dagger$ \\
\hline Alpine & 0.01 & 1.00 & $\begin{array}{l}\text { Onset: } 1 \text { May } \\
\text { Max. dates: } 30 \text { Jun-1 Aug }\end{array}$ \\
\hline Coniferous & 5.00 & 5.00 & No seasonal variation \\
\hline Shortgrass & 0.00 & 0.60 & $\begin{array}{l}\text { Onset: } 1 \text { May } \\
\text { Max. dates: } 30 \text { May-16 Jul }\end{array}$ \\
\hline \multicolumn{4}{|l|}{ Dry crops } \\
\hline Wheat & 0.00 & 4.00 & $\begin{array}{l}\text { Onset: } 16 \text { Mar } \\
\text { Max. dates: } 15 \text { May-9 Jun }\end{array}$ \\
\hline Fallow (weeds) & 0.00 & 0.03 & $\begin{array}{l}\text { Onset: } 10 \text { Jul } \\
\text { Max. dates: } 9 \text { Aug-31 Oct }\end{array}$ \\
\hline Wet crops & 0.00 & 6.00 & $\begin{array}{l}\text { Onset: } 15 \text { Apr } \\
\text { Max. dates: } 15 \text { May-16 Jul }\end{array}$ \\
\hline
\end{tabular}

$\dagger$ Phenology is presented for current climate scenarios. Green-up began 2 wk earlier with each $+2^{\circ} \mathrm{C}$, or 2 wk later with a $-2^{\circ} \mathrm{C}$.

Kittel and D. Ojima, unpublished data). In this region of distinct vegetation gradients based on precipitation and elevation, the coarse-resolution map by Küchler (1975) is probably fairly good. Several investigators have conducted validation studies of the EDC data base, and found that the land cover classification performed well (Zelt et al. 1995, Merchant et al. 1996, Zhu et al. 1996).

Most of the difference between current and potential land cover occurred through conversion of steppe grasses to dry crops (a wheat-fallow system where only half the land is planted at any time), or to irrigated crops (mostly corn) (Table 1). Other vegetation changes that occurred were conversion of some coniferous forests in the foothills and some deciduous forests along river corridors to croplands (Fig. 3). Because deciduous forests made up $<2 \%$ of total land cover for the South Platte, we do not report on deciduous forest processes. Soil rooting depth was derived from available water capacity maps of the State Soil Geographic Database (STATSGO) (Lytle 1993, Lammers et al. 1997).

LAI values and phenology were assigned to land cover types based on published literature values for all vegetation types except wheat (Table 2; Dickinson et al. 1986). LAI values for wheat were calculated from aboveground live wheat biomass (from Metherell et al. 1993), while wheat phenology for current climate, including green-up and harvest, was taken from Shanahan (1982). Maximum LAI was set to 6.0 for irrigated cropland. Maximum LAI for shortgrass steppe was 0.6, and for dryland wheat maximum LAI was set to 4.0. Half of the land area under dryland wheat is fallow at any given time, and we assigned a small LAI of 0.03 to weedy vegetation cover on fallow land during the late summer and fall (Metherell 1992). LAI for coniferous forests was constant at 5.0, while tundra increased LAI from a minimum of 0.01 to 1.0 over a growing season. Vegetation phenology for alpine, grassland, and dry crop vegetation types was cued to temperature, so that green-up began 2 wk earlier with every $+2^{\circ} \mathrm{C}$ temperature increase, or 2 wk later with a $-2^{\circ} \mathrm{C}$ temperature decrease.

We used weather data for calendar year 1992 from 119 weather stations for temperature, and from 177 weather stations for precipitation in the South Platte Basin, to drive the models (Colorado Climate Data 1992, Thornton et al. 1997). Colorado climate is notoriously variable, and 1992 was no exception (Hansen et al. 1978). Precipitation in February, April, and May was $50 \%$ of the $30-y r$ mean, while precipitation in March, June, and August was $200 \%$ of the 30-yr mean. Temperatures from February through May were $2-8^{\circ} \mathrm{C}$ greater than the $30-\mathrm{yr}$ average; they were $2-4^{\circ} \mathrm{C}$ less than the average from June through August (Colorado Climate Data 1992). Climate change simulations were made by altering the minimum and maximum daily temperature of the 1992 weather file by $-2^{\circ}$ and $+4^{\circ} \mathrm{C}$. These two temperature scenarios were chosen based on RHESSys simulations for a high-elevation watershed at the headwaters of the South Platte Basin (Baron et al. 1998). The cooler temperatures represent trends that have been observed for the Colorado Front Range over the past four decades (Williams et al. 1996, Stohlgren et al. 1998). Simulations of $+2^{\circ} \mathrm{C}$ warming in the headwater basin caused little change in model output from control runs, but a $+4{ }^{\circ} \mathrm{C}$ warming showed dramatic differences in processes, suggesting that a temperature threshold had been passed (Baron et al. 1998). We did not vary precipitation for these simulations because uniform changes in precipitation would never occur in our domain, and the complexities involved with attempting meaningful seasonal and spatial precipitation regimes were very great.

\section{RESUlTS}

\section{Effects of land cover change by land cover type}

Annual summaries.-Annual basin-wide net photosynthesis and transpiration increased by by $>80 \%$ due to the change in vegetation between potential and cur- 
TABLE 3. Ecosystem processes by land cover for current climate simulations under current vs. potential natural land cover

\begin{tabular}{|c|c|c|c|c|c|}
\hline & Steppe & $\begin{array}{c}\text { Dry } \\
\text { crop }\end{array}$ & $\begin{array}{l}\text { Wet } \\
\text { crop }\end{array}$ & $\begin{array}{c}\text { Current } \\
\text { basin } \\
\text { total } \ddagger\end{array}$ & $\begin{array}{c}\text { Poten- } \\
\text { tial } \\
\text { basin } \\
\text { total } \ddagger\end{array}$ \\
\hline \multicolumn{6}{|c|}{ Net photosynthesis } \\
\hline Annual & 411 & 496 & 1389 & 528 & 293 \\
\hline May & 90 & 209 & 404 & 124 & 56 \\
\hline \multicolumn{6}{|c|}{ Transpiration $\|$} \\
\hline Annual & 140 & 162 & 509 & 182 & 99 \\
\hline May & 30 & 70 & 145 & 42 & 18 \\
\hline \multicolumn{6}{|c|}{ Evaporation $\|$} \\
\hline Annual & 210 & 209 & 460 & 238 & 207 \\
\hline May & 16 & 22 & 88 & 27 & 18 \\
\hline
\end{tabular}

+ Dry crop is the combined model output for dry crop and fallow fields.

* Basin totals are areally weighted averages.

$\S$ Net photosynthesis is measured in $\mathrm{g} \mathrm{C} \cdot \mathrm{m}^{-2} \cdot \mathrm{mo}^{-1}$ for May, and $\mathrm{g} \mathrm{C} \cdot \mathrm{m}^{-2} \cdot \mathrm{yr}^{-1}$ for annual values.

|| Transpiration and evaporation are measured in $\mathrm{mm} / \mathrm{mo}$ for May, and $\mathrm{mm} / \mathrm{yr}$ for annual values.

rent land cover (Table 3). Evaporative losses, however, increased by only $15 \%$. Individual land cover types showed dramatic response (Table 3). Irrigated (wet) crops showed substantially greater photosynthesis and transpiration than dry crops or the original steppe vegetation. Evaporation from wet croplands was 120\% greater than that from steppe. Evaporation from nonirrigated crops differed from steppe by $3 \%$ or less. There was little change in alpine tundra or coniferous forest processes between current and potential land cover scenarios; their data are not shown.

Summaries for May. - An examination of these same processes for the month of May showed great basinscale differences in photosynthesis and transpiration rates between potential and current vegetation (Table 3). May was chosen as a representative month because vegetation is photosynthetically active in all South Platte vegetation types by that time of the year, yet rates of water fluxes and photosynthesis were expected to differ depending on climate variability. Both the wet crop and dry crop reach maximum LAI of 6 and 4 , respectively, by 15 May (day 135). However, shortgrass steppe does not reach its maximum LAI of 0.6 until 1 June (day 152), so it is still gaining leaf area through May. The shift in phenology from steppe to crops more than doubled net photosynthesis and water lost through transpiration for May of current vs. potential vegetation for the entire basin. Basin-wide evaporation in May increased by $50 \%$ due to land cover change.

Individual land cover types behaved very differently with land use change (Table 3). Dry crop photosynthesis and transpiration were more than twice as high as shortgrass steppe in May, with wet crop photosynthesis and transpiration nearly five times as high. Dry crops and wet crops evaporated $6 \mathrm{~mm}$ and $73 \mathrm{~mm}$ more than steppe, respectively.
Substantial spatial differences in photosynthesis and transpiration are evident between potential and current land cover on 1 June (Plate 1). Most of the change, as expected, occurred on the plains where there was conversion of steppe to croplands. Irrigated crops showed large increases in photosynthesis and transpiration, while the wheat-fallow showed increases or decreases in photosynthesis and transpiration rates depending on location.

\section{Effects of temperature changes by land cover type}

Annual results.-Cooler temperatures were beneficial to the dry and irrigated crops, but caused a decrease in native tundra, conifer, and steppe vegetation productivity (Table 4). Basin-wide, the increase in net productivity was only $3 \%$, so the overall effect of cooling was slight to negligible. Warming was quite detrimental to carbon gain across all vegetation types except tundra, due to increased plant respiration. The loss was most pronounced for dry crops, where net photosynthesis decreased by $27 \%$ compared with the current climate. Warmer spring temperatures at the highest elevations allowed tundra a longer growing season, causing photosynthesis to increase by $9 \%$. Annual productivity for the entire South Platte Basin declined by $16 \%$.

Annual transpiration rates decreased by almost $30 \%$ for alpine and coniferous vegetation types at cooler temperatures. Cooler temperatures also decreased transpiration rates in the steppe and grassland crops by $2-$ $16 \%$. Less water was evaporated throughout the basin with cooler temperatures, with the greatest decrease (27\%) occurring in tundra, and $13-22 \%$ less water evaporated from the other vegetation types. The net basin-wide effect of cooling was a $9 \%$ decrease in transpiration and a $15 \%$ decrease in evaporation. Climate warming had the opposite effect on basin-wide ET. The amount of water transpired from tundra, coniferous, steppe, dry crop, and wet crop vegetation increased by $50,25,8,15$, and $6 \%$, respectively, over the current climate control runs. Evaporation increased with warming for all vegetation types. The overall effect of basin warming was slightly more water transpired than under current climate, but $28 \%$ more water evaporated.

Results for May.-Carbon production was strongly suppressed with cooler temperatures (Table 4). The basin-wide decline was $25 \%$; alpine and steppe produced $73-83 \%$ less carbon with a $-2{ }^{\circ} \mathrm{C}$ cooling. Results for temperature warming were mixed. Warming was highly beneficial to alpine vegetation, and increased spring productivity by $>200 \%$. Steppe productivity also increased with warming, but conifer and crop vegetation decreased photosynthesis, again due to increased plant respiration. There was a 5\% decrease in basin-wide productivity with warming. There is variation within the mountain vegetation types that is obscured by the monthly summary for May: the highest elevation tundra and coniferous forest shows increased productivity with warmer temperatures on the 1 June snapshot, 


\section{Temperature Change}
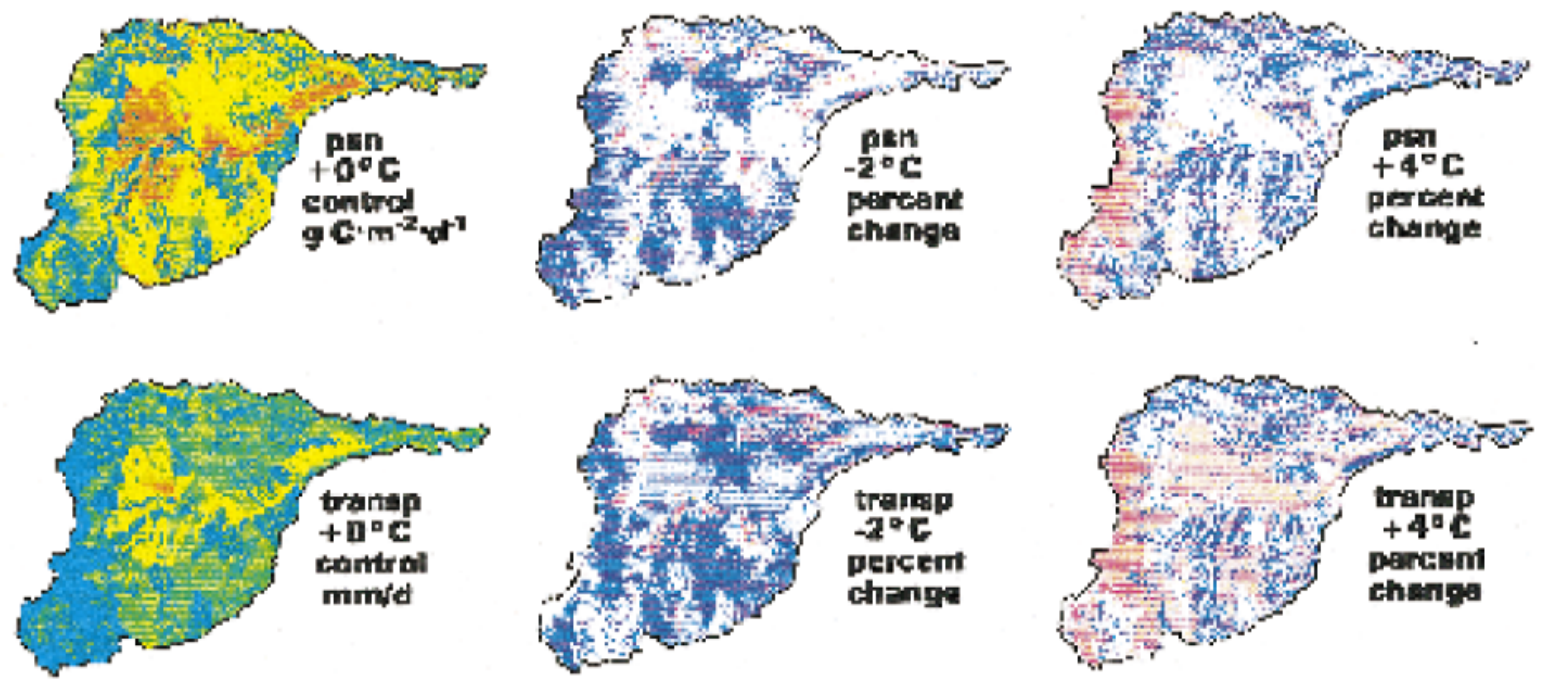

\section{Land Use Change}
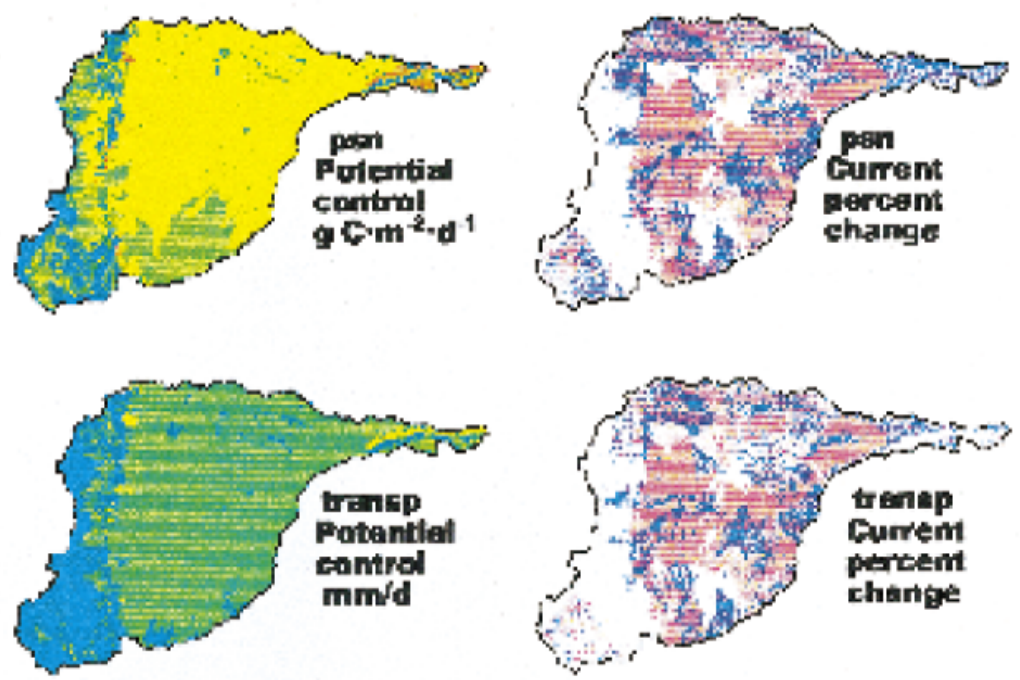

\section{Net Photosynthesls} or Transpiration g c $\cdot \mathrm{m}^{-2} \cdot \mathrm{d}^{-1}$ or $\mathrm{mm} / \mathrm{d}$

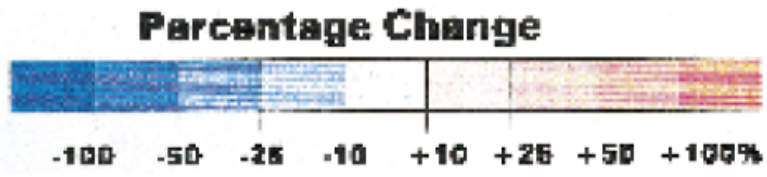

0.5 $\quad 0.5$ 1.0 $2.5 \quad 5.0 \quad 7.6 \quad 10.0$

Plate 1. Responses of net photosynthesis and transpiration to temperature changes (top) and land use change (bottom)

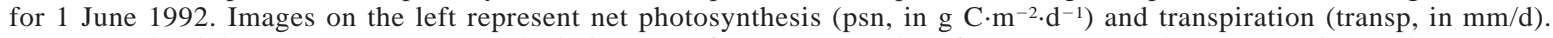
Images on the right represent percentage deviation away from current values for temperature change scenarios, and percentage deviation away from potential values for land use change scenarios. In percentage change images, warm colors depict an increase, while cool colors depict a decrease in carbon fixed or water transpired. White represents little or no change $( \pm 10 \%)$ from the original values. 
TABLE 4. RHESSys model output of annual and May net photosynthesis, transpiration, and evaporation for current land cover classes of the South Platte River Basin. Values shown are for the control scenario, generated from 1992 climate data. Percentages are deviations from the control run for $-2^{\circ} \mathrm{C}$ and $+4^{\circ} \mathrm{C}$ climate change scenarios.

\begin{tabular}{|c|c|c|c|c|c|c|}
\hline Output & Alpine & Coniferous & Steppe & Dry crop $\dagger$ & Wet crop & Basin total \\
\hline $\begin{array}{l}\text { Net photosynt } \\
\text { Annual } \\
-2^{\circ} \mathrm{C} \\
+4^{\circ} \mathrm{C}\end{array}$ & $\begin{array}{l}269 \\
-12 \% \\
+9 \%\end{array}$ & $\begin{array}{l}326 \\
-3 \% \\
-21 \%\end{array}$ & $\begin{array}{l}411 \\
-6 \% \\
-9 \%\end{array}$ & $\begin{array}{l}458 \\
+16 \% \\
-27 \%\end{array}$ & $\begin{array}{l}1389 \\
+2 \% \\
-12 \%\end{array}$ & $\begin{array}{l}528 \\
+3 \% \\
-16 \%\end{array}$ \\
\hline $\begin{array}{l}\text { May } \\
\quad-2^{\circ} \mathrm{C} \\
+4^{\circ} \mathrm{C}\end{array}$ & $\begin{array}{c}23 \\
-83 \% \\
+104 \%\end{array}$ & $\begin{array}{c}61 \\
-13 \% \\
-13 \%\end{array}$ & $\begin{array}{c}90 \\
-73 \% \\
+29 \%\end{array}$ & $\begin{array}{l}105 \\
-15 \% \\
-39 \%\end{array}$ & $\begin{array}{l}404 \\
-1 \% \\
-7 \%\end{array}$ & $\begin{array}{l}124 \\
-25 \% \\
-5 \%\end{array}$ \\
\hline $\begin{array}{l}\text { Transpiration } \| \\
\text { Annual } \\
-2^{\circ} \mathrm{C} \\
+4^{\circ} \mathrm{C}\end{array}$ & $\begin{array}{c}34 \\
-29 \% \\
+50 \%\end{array}$ & $\begin{array}{c}95 \\
-27 \% \\
+25 \%\end{array}$ & $\begin{array}{l}140 \\
-16 \% \\
+8 \%\end{array}$ & $\begin{array}{c}160 \\
-2 \% \\
-15 \%\end{array}$ & $\begin{array}{l}509 \\
-11 \% \\
+6 \%\end{array}$ & $\begin{array}{l}182 \\
-9 \% \\
+3 \%\end{array}$ \\
\hline $\begin{array}{l}\text { May } \\
\quad-2^{\circ} \mathrm{C} \\
+4^{\circ} \mathrm{C}\end{array}$ & $\begin{array}{c}3 \\
-89 \% \\
+223 \%\end{array}$ & $\begin{array}{c}15 \\
-33 \% \\
+33 \%\end{array}$ & $\begin{array}{c}30 \\
-80 \% \\
+53 \%\end{array}$ & $\begin{array}{c}35 \\
-23 \% \\
-29 \%\end{array}$ & $\begin{array}{l}145 \\
-10 \% \\
+10 \%\end{array}$ & $\begin{array}{c}42 \\
-33 \% \\
+12 \%\end{array}$ \\
\hline $\begin{array}{c}\text { Evaporation } \| \\
\text { Annual } \\
-2^{\circ} \mathrm{C} \\
+4^{\circ} \mathrm{C}\end{array}$ & $\begin{array}{l}139 \\
-27 \% \\
+43 \%\end{array}$ & $\begin{array}{l}222 \\
-13 \% \\
+23 \%\end{array}$ & $\begin{array}{l}210 \\
-13 \% \\
+19 \%\end{array}$ & $\begin{array}{l}206 \\
-13 \% \\
+20 \%\end{array}$ & $\begin{array}{l}460 \\
-22 \% \\
+50 \%\end{array}$ & $\begin{array}{l}238 \\
-15 \% \\
+28 \%\end{array}$ \\
\hline $\begin{array}{l}\text { May } \\
\quad-2^{\circ} \mathrm{C} \\
+4^{\circ} \mathrm{C}\end{array}$ & $\begin{array}{c}14 \\
-64 \% \\
+78 \%\end{array}$ & $\begin{array}{c}30 \\
-13 \% \\
+13 \%\end{array}$ & $\begin{array}{c}16 \\
-19 \% \\
+13 \%\end{array}$ & $\begin{array}{l}18 \\
-5 \% \\
+5 \%\end{array}$ & $\begin{array}{c}88 \\
-23 \% \\
+55 \%\end{array}$ & $\begin{array}{c}27 \\
-19 \% \\
+30 \%\end{array}$ \\
\hline
\end{tabular}

$\dagger$ Because half of the area under dry crops is fallow at any given time, values reported for this category are the average of model results for crop and fallow land.

$\ddagger$ Basin totals are areally weighted averages

$\S$ Net photosynthesis is measured in $\mathrm{g} \mathrm{C} \cdot \mathrm{m}^{-2} \cdot \mathrm{mo}^{-1}$ for May, and $\mathrm{g} \mathrm{C} \cdot \mathrm{m}^{-2} \cdot \mathrm{yr}^{-1}$ for annual values.

$\|$ Transpiration and evaporation are measured in $\mathrm{mm} / \mathrm{mo}$ for May, and $\mathrm{mm} / \mathrm{yr}$ for annual values.

while lower elevation coniferous forests display negative changes in net photosynthesis (Plate 1).

May transpiration responded strongly to warming and cooling in alpine, coniferous, and steppe vegetation (Table 4). Both wet and dry crops transpired less with cooling, and dry crops transpired less with warming. The actual amount of water transpired, except for irrigated crops, ranged from 3 to $35 \mathrm{~mm}$ in the control runs, so the amount of water transpired per square meter from each vegetation type in May was small. Transpiration rates for 1 June show the extent of spatial variation; irrigated crops transpire the most water, while tundra and conifers transpire the least (Plate 1). Dry cropland showed spatial variation in response to warming or cooling; some areas showed no response to temperature variation, while others increased or decreased productivity and transpiration with both warming and cooling based on topographic characteristics (Plate 1).

May evaporation was most responsive to climate change in tundra, decreasing $64 \%$ and increasing $136 \%$ with cooling and warming, respectively (Table 4). Conifers and the grasses (except dry crop) showed less of a response to temperature, but evaporation decreased with cooling and increased with warming. The amount of water transpired in May was greatest from irrigated crops. Basin-wide, warming and cooling changed evaporative losses by $20-30 \%$.

\section{Individual hillslope responses}

Influence of topographic location and climate.Three hillslopes were selected to represent different land covers to track ecosystem processes related to land use change (Table 5, Fig. 3). Hillslope 111 had the greatest elevational range, but only slight change between potential and current land covers. The change resulted from conversion of steppe and some conifer to wheat-fallow, and a loss of $26 \mathrm{~km}^{2}$ of tundra, presumably by conversion to conifer. Approximately $60 \%$ of hillslope 140 was converted from shortgrass steppe to dry and fallow cropland, and $88 \%$ of hillslope 40 was converted to irrigated cropland. Time series of ecosystem processes by hillslopes reveal changes due to climate and geographic location, as well as changes brought about by land cover change (Fig. 4). The influence of location was very evident from comparing runoff between hillslopes (Fig. 4a). Runoff from mountain hillslope 111 was driven by snowmelt, increasing in early May (day 120), peaking in June, and declining through July (Fig. 4a). Runoff from the dry crop and steppe hillslope 140 was driven by rainfall, and surface flow only occurred for a short while during and after rain events. Runoff from the irrigated crop hillslope 40 , which was driven by irrigation and rainfall, was sustained and high during the period of irrigation.

The dynamics of soil moisture were different between mountains and plains (Fig. 4b). Water content 
TABle 5. Descriptions of three (out of 136) hillslopes selected to show effects of land use change on ecosystem dynamics. Soil rooting depths are means, with standard deviations in parentheses.

\begin{tabular}{|c|c|c|c|c|c|c|}
\hline Hill & $\begin{array}{l}\text { Elevation } \\
\text { range }(m)\end{array}$ & $\begin{array}{l}\text { Total } \\
\text { area } \\
\left(\mathrm{km}^{2}\right)\end{array}$ & $\begin{array}{c}\text { Soil root } \\
\text { depth }(\mathrm{cm})\end{array}$ & $\begin{array}{l}\text { Days (length) of } \\
\text { growing season } \dagger\end{array}$ & $\begin{array}{l}\text { Potential vegetation } \\
\text { types }\left(\mathrm{km}^{2}\right)\end{array}$ & $\begin{array}{l}\text { Current vegetation } \\
\text { types }\left(\mathrm{km}^{2}\right)\end{array}$ \\
\hline 111 & $1815-3900$ & 731 & $46(13)$ & $\begin{array}{l}89-300(211) \\
89-300(211)\end{array}$ & \multirow{2}{*}{$\begin{array}{l}\text { alpine }(307) \\
\text { coniferous }(413) \\
\text { steppe }(11) \\
\text { steppe }(641)\end{array}$} & \multirow{3}{*}{$\begin{array}{l}\text { alpine }(281) \\
\text { coniferous }(414) \\
\text { dry/fallow (36) } \\
\text { steppe }(270) \\
\text { dry/fallow }(371) \\
\text { steppe }(52) \\
\text { wet crop }(365)\end{array}$} \\
\hline 140 & $1628-2083$ & 641 & $60(0)$ & $\begin{array}{r}120-226(106) \\
77-226(149)\end{array}$ & & \\
\hline 40 & $1394-1488$ & 417 & $58(3)$ & $\begin{array}{l}120-226(106) \\
104-226(122)\end{array}$ & steppe (417) & \\
\hline
\end{tabular}

$\dagger$ Top numbers are potential vegetation growing season; bottom numbers are current vegetation growing season. Days of year begin 1 January.

was a function of porosity and depth, as well as amount of available water. Mountain soils in hillslope 111 averaged $46 \mathrm{~cm}$ in depth. These soils were dry through the winter, and began to gain moisture around day 95 (April 5). The volumetric soil water content ranged
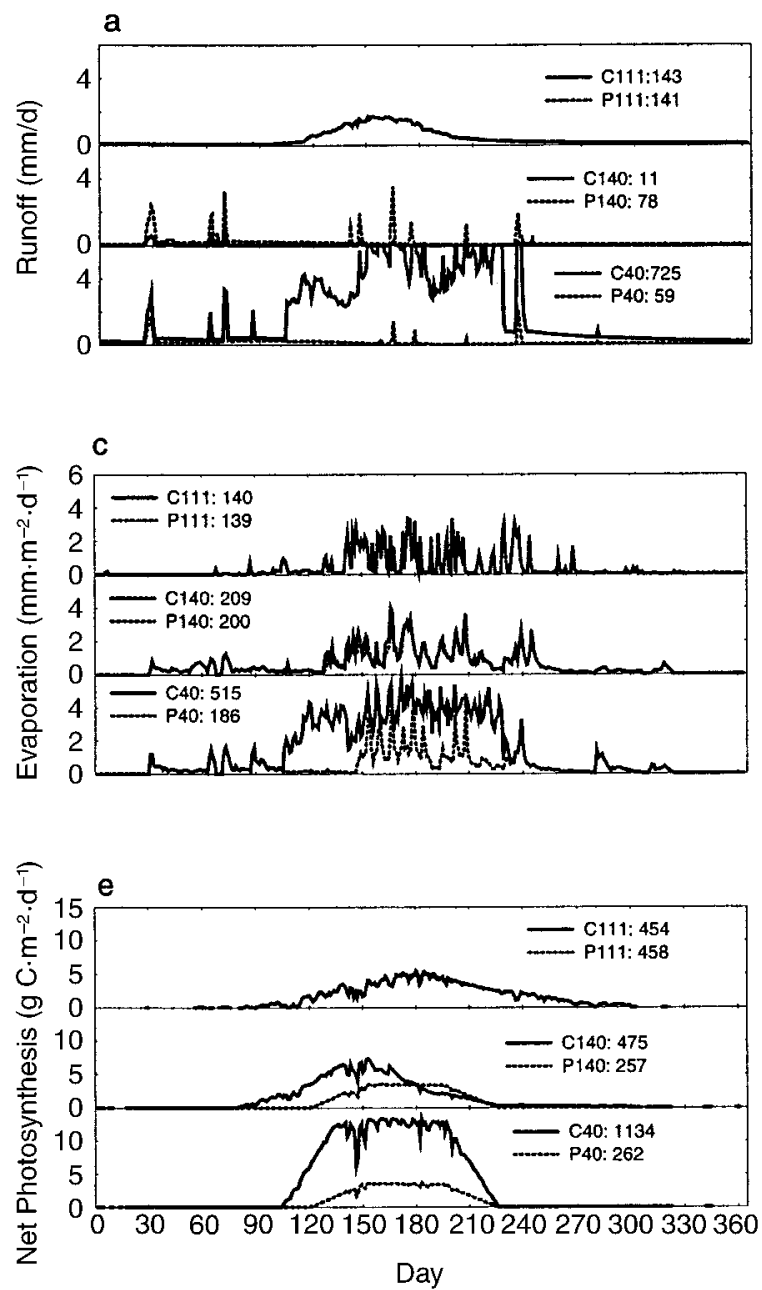

from 10 to $24 \%$ (40\% is saturation) between early April and the end of August (Fig. 4b). Plains soils in hillslopes 40 and 140 ranged from 50 to $60 \mathrm{~cm}$ depth. They exhibited their highest soil moisture content in the spring and winter, and lowest during the growing
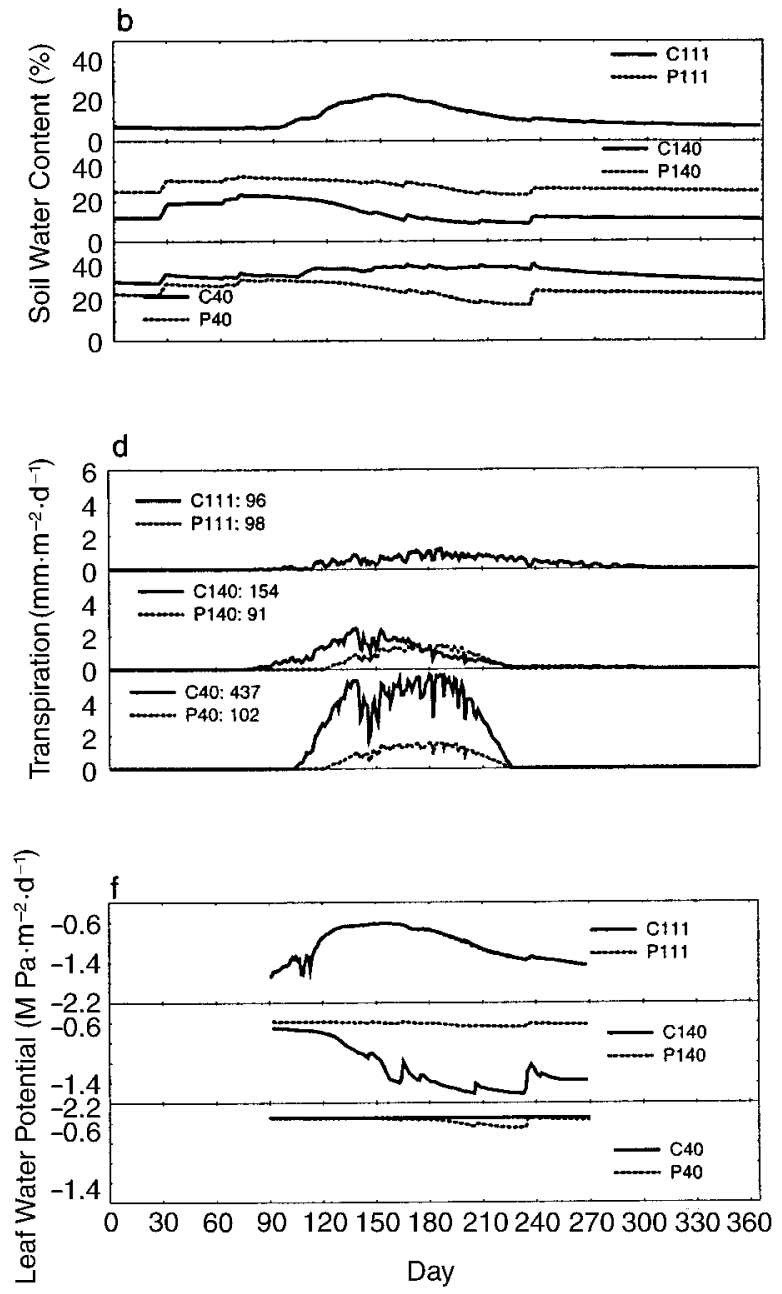

FIG. 4. Individual hillslope responses to changes in land cover, showing (a) hillslope outflow, (b) soil water content, (c) evaporation, (d) transpiration, (e) net photosynthesis, and (f) leaf water potential. Solid lines are potential land cover; dotted lines are current land cover. Notation in key is Potential, or Current, hillslope number, and annual total of each variable. Please refer to Fig. 3 and Table 5 for locations of hillslopes and land cover types. 
season. One can see the effect of individual rain storms. Water losses through evaporation and transpiration from the mountain hillslope were less than those from the other two hillslopes (Fig. 4c, d). Transpiration in the mountains was less seasonally dynamic than transpiration from the plains hillslopes, but the total amount of water transpired was similar between mountain and steppe potential vegetation.

Mountain hillslope 111 had a 211-d growing season, with photosynthesis beginning at lower elevations around day 89 (beginning of May) and continuing until day 300 (end of October) (Fig. 4e). Elevational differences can be clearly seen in the upper left corner of Plate 1, where the highest elevations show 0.0-2.5 g $\mathrm{C} \cdot \mathrm{m}^{-2} \cdot \mathrm{d}^{-1}$, compared with $2.6-5.0 \mathrm{~g} \mathrm{C} \cdot \mathrm{m}^{-2} \cdot \mathrm{d}^{-1}$ in the lower elevation reaches of the basin. The steppe grasses had a shorter growing season due to water stress, beginning on day 120 (beginning of May) and ending on day 226 (10 August).

The simulated predawn leaf water potentials provide an estimate of water stress by describing stomatal resistances, and thus constrain the upper limits of daily transpiration. Transpiration occurred freely through most of the growing season in the mountain hillslope, rising in the spring and declining at the end of summer. Explanations for simulated leaf water potentials for the grass vegetation types are more complex (Fig. 4f). Low LAI values for steppe create low water demand, so that potential vegetation did not undergo much, if any, water stress. There were great differences in leaf water potentials between wheat-fallow in hillslope 140 and irrigated crops in hillslope 40, due to soil water availability. Greater LAI but no additional water supply induced negative leaf water potentials in the dry crops of hillslope 140, whereas unlimited irrigation water kept leaf water potentials high in wet crops of hillslope 40.

Influence of land use change.-There was little land cover change to hillslope 111 , and these small changes did not alter runoff or soil water content (Fig. 4a, b). In contrast, large differences occurred on the plains hillslopes. There was less runoff and soils were much drier with wheat/fallow than with potential steppe vegetation on hillslope 140. Because irrigation maintained soil moisture, runoff and volumetric soil water content were much higher in the irrigated crops of hillslope 40 than in the steppe. Runoff from irrigated crops was high and continuous from the onset of irrigation until harvest. Evaporation did not differ between steppe and wheat-fallow vegetation in hillslope 140 , but was three times greater in hillslope 40, where water was augmented by unlimited irrigation to crops (Fig. 4c).

Annual net carbon production increased by a factor of four, from 262 to $1134 \mathrm{~g} \mathrm{C} \cdot \mathrm{m}^{-2} \cdot \mathrm{yr}^{-1}$, and the amount of water transpired increased by a factor of four, from 102 to $437 \mathrm{~mm} / \mathrm{yr}$, when steppe was converted to irrigated crops in hillslope 40 (Fig. 4d, e). The mixed wet crop and steppe type accumulated $1134 \mathrm{~g} \mathrm{C} / \mathrm{m}^{2}$ compared with $262 \mathrm{~g} \mathrm{C} / \mathrm{m}^{2}$ for the steppe-only potential vegetation in hillslope 40. Conversion of shortgrass steppe to mixed steppe and dryland crops in hillslope 140 also resulted in net $\mathrm{C}$ gain of $218 \mathrm{~g} \mathrm{C} / \mathrm{m}^{2}$, an increase of $85 \%$. Photosynthesis and respiration changes were negligible between current and potential vegetation for the mountain hillslope 111, where land cover changes were minimal.

Soil water was lower in the dry crop vegetation relative to steppe, due to greater ET losses in the croplands. Soil water content in the dry crops rarely exceeded $20 \%$, and was between 10 and $15 \%$ through the growing season. Soil water was $12 \%$ greater throughout the year for the steppe (Fig. 4b). While steppe grasses were never stressed by low predawn water potentials, the wheat-fallow vegetation was subjected to values of -1.8 to $-2.0 \mathrm{MPa}$ late in the growing season (Fig. 4f).

Land use change from steppe to croplands caused an increase in early-season photosynthesis and transpiration. Rates of net photosynthesis increased earlier and decreased earlier in the mixed dry crop and steppe land cover than for steppe in hillslope 140. For hillslope 40, rates for net photosynthesis began to increase earlier in the mixed wet crop and steppe current land cover than in the steppe potential land cover.

\section{DISCUSSION}

\section{Comparison of RHESSys results with measured values}

The simulation results for annual above- and belowground net primary productivity agreed well with measured values for the different vegetation types (Table 6). The RHESSys output for tundra was $269 \mathrm{~g}$ $\mathrm{C} \cdot \mathrm{m}^{-2} \cdot \mathrm{yr}^{-1}$ (108 $\mathrm{g} \mathrm{C}$ aboveground if one assumes that belowground productivity is $150 \%$ that reported for aboveground productivity) (Webber and May 1977). This fell within the reported ranges of measured aboveground production of $40-140 \mathrm{~g} \mathrm{C} \cdot \mathrm{m}^{-2} \cdot \mathrm{yr}^{-1}$ (Webber and May 1977, Bowman et al. 1993, Walker et al. 1994). Coniferous forest productivity, simulated at $326 \mathrm{~g}$ $\mathrm{C} \cdot \mathrm{m}^{-2} \cdot \mathrm{yr}^{-1}$, fell within the $137-344 \mathrm{~g} \mathrm{C} \cdot \mathrm{m}^{-2} \mathrm{yr}^{-1}$ range of above- and belowground productivity measured by Arthur and Fahey (1992). Our simulated grassland above- and belowground result, $411 \mathrm{~g} \mathrm{C} \cdot \mathrm{m}^{-2} \cdot \mathrm{yr}^{-1}$, or $\sim 164 \mathrm{~g}$ aboveground $\mathrm{C} \cdot \mathrm{m}^{-2} \cdot \mathrm{yr}^{-1}$, was slightly higher than the range of $100-150 \mathrm{~g} \mathrm{C} \cdot \mathrm{m}^{-2} \cdot \mathrm{yr}^{-1}$ reported for aboveground productivity by Sala et al. (1988). Crop comparisons are not presented, because while crop yield is readily available, total aboveground production for crops is rarely measured.

Although we made no attempt to develop a hydrologic budget with our simulations, our modeled water parameters were within the same order of magnitude as the measured values presented by Dennehy et al. (1993; Table 6). The simulated precipitation for 1992, $2.54 \times 10^{10} \mathrm{~m}^{3} / \mathrm{yr}$, was close to the long-term mean 
TABLE 6. Simulated and measured values for productivity and hydrologic parameters for the South Platte Basin.

\begin{tabular}{|c|c|c|}
\hline Parameters & $\begin{array}{l}\text { Simulated } \\
\text { values }\end{array}$ & Observed values \\
\hline \multicolumn{3}{|l|}{ Net primary production $\left(\mathrm{g} \mathrm{C} \cdot \mathrm{m}^{-2} \cdot \mathrm{yr}^{-1}\right)$} \\
\hline Tundra, aboveground & 108 & $\begin{array}{l}\text { 40-140 (Webber and May 1977, Bowman et al. 1993, Walker } \\
\text { et al. 1994) }\end{array}$ \\
\hline Coniferous, above- and belowground & 326 & 137-344 (Arthur and Fahey 1992) \\
\hline Shortgrass, aboveground & 164 & $100-150$ (Sala et al. 1988) \\
\hline \multicolumn{3}{|l|}{ Hydrologic inputs $\left(\mathrm{m}^{3} / \mathrm{yr}\right)$} \\
\hline Precipitation & $25432 \times 10^{6}$ & $24680 \times 10^{6}$ (Dennehy et al. 1993$)$ \\
\hline Trans-basin diversions & not simulated & $494 \times 10^{6}($ Dennehy et al. 1993$)$ \\
\hline \multicolumn{3}{|l|}{ Hydrologic outputs $\left(\mathrm{m}^{3} / \mathrm{yr}\right)$} \\
\hline Evaporation & $14688 \times 10^{6}$ & \\
\hline Transpiration & $11220 \times 10^{6}$ & \\
\hline Sublimation & $401 \times 10^{6}$ & \\
\hline Evapotranspiration (nonirrigated) & & $21842 \times 10^{6}$ (Dennehy et al. 1993$)$ \\
\hline Consumptive water use & & $2382 \times 10^{6}($ Dennehy et al. 1993$)$ \\
\hline Reservoir and stream & & $494 \times 10^{6}($ Dennehy et al. 1993$)$ \\
\hline $\begin{array}{l}\text { Sum evaporation, transpiration, and sub- } \\
\text { limation }\end{array}$ & $26309 \times 10^{6}$ & $24718 \times 10^{6}$ \\
\hline Discharge & $6162 \times 10^{6}$ & $485 \times 10^{6}($ Dennehy et al. 1993$)$ \\
\hline
\end{tabular}

precipitation of $2.47 \times 10^{10} \mathrm{~m}^{3} / \mathrm{yr}$. The combined simulated flux of moisture to the atmosphere, evaporation, transpiration, and sublimation was $2.66 \times 10^{10} \mathrm{~m}^{3} / \mathrm{yr}$, compared with the estimated $2.47 \times 10^{10} \mathrm{~m}^{3} / \mathrm{yr}$ of Dennehy et al. (1993). Discharge values were not as well matched with the measured values, probably because we made no attempt to match the amount of water we used to irrigate the wet crops with actual values.

The conversion of $21000 \mathrm{~km}^{2}$ steppe and $2300 \mathrm{~km}^{2}$ coniferous vegetation to dry and irrigated cropland resulted in $80 \%$ more primary production for the South Platte Basin (Table 3). In contrast, a $-2^{\circ} \mathrm{C}$ cooling increased basin production by only $3 \%$, and a $+4{ }^{\circ} \mathrm{C}$ warming decreased basin productivity by $16 \%$ (Table 4). Clearly, land use has a greater influence on regional carbon stocks than does warming or cooling. In this, our findings corroborate those of Burke, Schimel, and Parton and their colleagues (Parton et al. 1987, Schimel et al. 1990, Burke et al. 1991).

Basin-wide evaporative losses increased by $31 \%$ as a result of land use change, compared with a decrease of $15 \%$ from cooling and an increase of $28 \%$ for warming. Climate warming, therefore, was as important to the regional evaporative flux as land use change. Transpiration increased by $84 \%$ as a result of land use change, whereas there was very little basin-wide response to cooling and warming, with changes of $-9 \%$ and $+3 \%$, respectively. The increase in the transpiration flux reflects the marked increase in the LAI of lands planted to crops.

Basin-wide estimates are somewhat misleading, since very different dynamics were displayed by the individual vegetation types. Crops receiving irrigation water lost far more to the atmosphere via transpiration and evaporation than did wheat-fallow and steppe. This illustrates that land use change was important, but perhaps more important was the availability of irrigation water. The total annual water lost to the atmosphere from steppe or dry crops was 350 and $366 \mathrm{~mm}$, respectively. These values are very close to the longterm precipitation mean of $334 \mathrm{~mm}$ for the plains part of the South Platte Basin. In contrast, the wet crops lost $969 \mathrm{~mm}$ water via evaporation and transpiration, clearly a result of additional water supplies.

The irrigated croplands also lost a large amount of water via discharge, as was seen for hillslope 40 in Fig. 4a. Runoff from the irrigated land was $>700 \mathrm{~mm}$, compared with $59 \mathrm{~mm}$ from this hillslope with shortgrass steppe. We have no way of verifying actual loss from this hillslope, but there is anecdotal evidence to suggest that the large discharge is not unreasonable. Irrigation accounts for $93 \%$, or $2215 \times 10^{6} \mathrm{~m}^{3} / \mathrm{d}$, of consumptive water use of South Platte Basin water, and irrigation return flows are $4610 \mathrm{~m}^{3} / \mathrm{d}$ (Dennehy et al. 1993). In the mid-1800s, surface flow in the South Platte River disappeared each summer for the last $200 \mathrm{~km}$ of river before its confluence with the North Platte. Since 1910 the river has remained perennial due to irrigation development and irrigation return flows (NRC 1992).

Annual evaporation decreased by $13 \%$ in both steppe and dry crops with cooling, and increased by $20 \%$ with warming (Table 4). Losses via transpiration were similar for steppe; less water was transpired with cooling and more was transpired with warming. Transpiration from dry crops, on the other hand, decreased only slightly (2\%) with cooling, and decreased substantially $(15 \%)$ with warming. The mean annual soil water content for dry cropland from hillslope 140 was $28 \%$ with current climate. Annual soil water dropped to $9 \%$ with $4^{\circ} \mathrm{C}$ warming, partly due to a longer growing season of $149 \mathrm{~d}$ with warmer climate, compared with $106 \mathrm{~d}$ under the current climate scenario. Measured ranges for soil moisture for north-central Colorado are 20$30 \%$ moisture at field capacity, and $8-10 \%$ at wilting 
point (Lapitan and Parton 1996). Decreased transpiration and a longer growing season were thus the result of inadequate soil moisture and high vapor pressure deficits for plant growth, a conclusion that is corroborated by a loss of $27 \%$ productivity in dry croplands and increased evaporation under the warming scenario.

Temperature change resulted in significant alterations in hydrologic and other ecosystem properties. Tundra, especially in the spring, exhibited a strong response to temperature. May is a critical time for tundra vegetation, and there was a strong decline in production (83\%) from 23 to $4 \mathrm{~g} \mathrm{C} \cdot \mathrm{m}^{-2} \cdot \mathrm{mo}^{-1}$ when the current temperatures were cooled. There was an even stronger increase, $104 \%$ more plant productivity, or $47 \mathrm{~g}$ $\mathrm{C} \cdot \mathrm{m}^{-2} \cdot \mathrm{mo}^{-1}$, with warming. Water losses via transpiration and evaporation were equally responsive to temperature changes, also primarily in the spring, although the absolute volumes of water were not great. May transpiration losses increased $223 \%$ over the control, to reach nearly $10 \mathrm{~mm}$, and evaporation increased by $36 \%$ to $19 \mathrm{~mm}$. In contrast to the plains vegetation, water was not limiting to productivity or evaporative water loss. Under the current climate scenario, $173 \mathrm{~mm}$ was evaporated or transpired annually to the atmosphere from tundra, far lower than measured mean annual precipitation of 1099 from Loch Vale Watershed.

The coniferous vegetation type was a broad collection of forest vegetation ranging from open ponderosa pine savanna below $2800 \mathrm{~m}$ elevation and on southfacing slopes, through dense "dog-hair" stands of lodgepole pine between 2500 and $2900 \mathrm{~m}$, to mesic Englemann spruce and subalpine fir on north-facing slopes and above $2900 \mathrm{~m}$ (Stohlgren and Bachand 1997). Soil depths for forest hillslopes were variable, ranging from an estimated $15 \mathrm{~cm}$ depth to over $60 \mathrm{~cm}$, contributing to the complex response predicted from such different areas. Responses to climate variation differ among species and with soil depth, so our lumped approach should be taken only as a general guide of forest behavior. For example, low elevations underwent water stress at the same time that high elevations were saturated with snowmelt water. Overall, plant productivity declined with both warming and cooling scenarios, but for different reasons. Low-elevation forest soils dried to below wilting point earlier with warming, preventing photosynthesis. The onset of the growing season was delayed with cooling by $\sim 11 \mathrm{~d}$. Transpiration and evaporation declined with cooling and increased with warming. The combined annual water lost through evaporation and transpiration $(317 \mathrm{~mm})$ is slightly less than the measured mean annual precipitation of 432 $\mathrm{mm}$ at Estes Park. With warming, evaporative and transpiration losses increased to $392 \mathrm{~mm}$ for the entire forest vegetation band, so it is likely that at the lowest elevations PET exceeded ET, creating water stress. Field capacity for forest soil moisture has been reported as $30 \%$, and wilting point as $20 \%$ (Sanford et al. 1991). The annual mean soil water holding content for hill- slope 111 was $28 \%$ under the control climate, and declined to $24 \%$ with warming. Again, however, our results did not take into account the extreme spatial variability of the coniferous vegetation type.

Our warming and cooling experiments did not include any influence of increasing $\mathrm{CO}_{2}$. There is some evidence that the changes in plant and community dynamics brought about by elevated $\mathrm{CO}_{2}$ will be complex. Polley et al. (1996) discuss possible encroachment of woody plants onto grasslands because elevated $\mathrm{CO}_{2}$ often increases nitrogen use efficiency and growth of woody and other $\mathrm{C}_{3}$ plants, and increases tolerance of $\mathrm{C}_{3}$ plants to heat and drought. Short-term experiments have shown that rising levels of $\mathrm{CO}_{2}$ shift the competitive balance to favor $\mathrm{C}_{3}$ over $\mathrm{C}_{4}$ plants, but it is not yet known whether this is true over the long term (Morse and Bazzaz 1994, Polley et al. 1996). Elevated $\mathrm{CO}_{2}$ increases water use efficiency; in water-limited environments this should increase primary production (Polley et al. 1996). Over the long term, we expect no net change in water flux for the South Platte Basin, however, because the increased soil moisture brought about by elevated $\mathrm{CO}_{2}$ will be offset by the increased leaf area (Ojima et al. 1993). Our results are similar to RHESSys simulations of wetter regions of North America, where fertilization with $\mathrm{CO}_{2}$ increased respiration significantly, but did not have a great effect on water fluxes or net photosynthesis (Band et al. 1996).

Response to regional land use change combined with global change will be more complex than we have portrayed. Land cover change exerted a large influence on annual plant productivity and water fluxes when grasslands were converted to crops, while the effect of temperature change on productivity and water fluxes was stronger in the mountain vegetation. This point emphasizes the importance of topographic and climatic complexity to understanding regional responses (Lammers et al., 1997). Recent records suggest that cooling is occurring in the mountains coincident with warming on the plains (Williams et al. 1996, Chase et al. 1998, Stohlgren et al. 1998). Our results should be used more as an heuristic tool, therefore, than as interpretation of future responses.

\section{Implications for feedbacks to atmosphere and regional climate}

There is a large and well-established body of literature describing the effects of humans on local, regional, and global environments (see, for example, Goudie 1990, Turner et al. 1990). There is no question that human activity has altered landscapes through deforestation, grazing, and agriculture, for thousands of years (McDowell et al. 1990). There is increasing evidence that, in addition to altering processes occurring at the land surface, irrigated agriculture can alter regional climate. Studies of the U.S. southern Great Plains have documented increases in the severity and 
frequency of summer storms and decreases in summer temperatures accompanying irrigation (Beebe 1974, Barnston and Schickedanz 1984, Rabin and Martin 1996). Pielke et al. (1997) have suggested that the cumulative effects of regional land use changes on climate may amount to a global-scale force in climate change.

Land surface energy fluxes are influenced by albedo, surface roughness, and especially moisture flux (Copeland et al. 1996). Water vapor is globally the most significant greenhouse gas, and may also be a major influence on regional climate dynamics (Chase et al. 1996). Our simulations suggest that $420 \mathrm{~mm}$ of water from the South Platte Basin is transmitted to the atmosphere from agricultural lands (sum of annual transpiration and evaporation from Table 4), up from a simulated $306 \mathrm{~mm}$ from pre-settlement vegetation. Our results strongly suggest that more moisture is evaporated and transpired and for a longer period during the growing season in dry and especially irrigated croplands. Mesoscale model results describe the physics by which the added moisture influences the climate through increasing convective instability enhancing local circulations (Anthes 1984, Segal et al. 1989, Lee 1992, Seth and Giorgi 1996, Chase et al. 1998). Chase et al. (1998), in simulations of the South Platte Basin climate with the Regional Atmospheric Modeling System (RAMS), have shown that land use change from native grasses to agriculture and urbanization could produce a regional cooling effect throughout the entire basin, including mountainous zones. Records of climate, river discharge, and seedling migration to lower elevations corroborate such a regional cooling (Williams et al. 1996, Stohlgren et al. 1998).

It is abundantly clear that water use change, more than land use change, is driving the responses observed in our simulations. Much of this water is not locally obtained. Native water does not drive land use or climate change in the South Platte Basin. "The West is defined . . . by inadequate rainfall. We can't create water, or increase the supply. We can only hold back and redistribute what there is," wrote Wallace Stegner (1987:6). Irrigation in the western United States leads to significant seasonal and spatial redistribution of water, and this influences the flux of water vapor into the atmosphere. Water for irrigation, and increasingly, for urban growth, is redirected from the South Platte headwaters and from the Colorado and Arkansas river basins (NRC 1992). The South Platte Basin water transfers are among the largest in the country, and support highly productive farming in eastern Colorado (NRC 1992). Much has been written about the consequences, ecological, as well as economic and social, of large western interbasin water transfers, including those that supply the growers and residents of the South Platte Basin. Water transfers always have repercussions; while they benefit those communities that receive and can profit by additional water, dewatered communities suffer.
Ecological repercussions are complex. High-elevation and western-slope aquatic and riparian communities have suffered from inadequate volumes, while irrigation return flows have changed the South Platte from seasonally dry to perennial (NRC 1992). The results from our RHESSys simulations suggest yet one more environmental change caused by water redistribution: transpiration losses of water sufficient to change the regional climate.

\section{ACKNOWLEDGMENTS}

We thank Robin Kelly, Steve Running, Ray Hunt, Rob Kremer, Hank Fisher, Peter Thornton, and Brian Newkirk for help with this research, which was supported by USGS Grant COLR-R92-0201, 140, NOAA NA36GP0378, and NASA EOS NAGW-2662. Jonathan Foley and an anonymous reviewer improved the manuscript through constructive comments. This is a contribution of the Colorado Rockies Global Change Project.

\section{Literature Cited}

Anthes, R. A. 1984. Enhancement of convective precipitation by mesoscale variations in vegetative covering in semiarid regions. Journal of Climate and Applied Meteorology 23:541-554.

Arthur, M. A., and T. J. Fahey. 1992. Biomass and nutrients in an Englemann spruce-subalpine fir forest in north-central Colorado: pools, annual production, and internal cycling. Canadian Journal of Forest Research 22:315-325.

Band, L. E. 1993. Effect of land surface representation on forest water and carbon budgets. Journal of Hydrology 150: 749-772.

- 1994. Development of a landscape ecological model for management on Ontario forests: Phase 2-extension over an east/west gradient over the province. Ontario Forest Resources Institute, Ontario Ministry of Natural Resources Report 17.

Band, L. E., D. S. Mackay, I. F. Creed, R. Semkin, and D. Jeffries. 1996. Ecosystem processes at the watershed scale: sensitivity to potential climate change. Limnology and Oceanography 41:928-938.

Band, L. E., P. Patterson, R. Nemani, and S. W. Running. 1993. Forest ecosystem processes at the watershed scale: incorporating hillslope hydrology. Agricultural and Forest Meteorology 63:93-126.

Band, L. E., D. L. Peterson, S. W. Running, J. Coughlan, R. Lammers, J. Dungan, and R. Nemani. 1991. Forest ecosystem processes at the watershed scale: basis for distributed simulation. Ecological Modeling 56:171-196.

Barnston, A. G., and P. T. Schickedanz. 1984. The effect of irrigation on warm season precipitation in the southern great plains. Journal of Climate and Applied Meteorology 23:865-888.

Baron, J., editor. 1992. Biogeochemistry of a subalpine ecosystem: Loch Vale Watershed. Springer-Verlag, New York, New York, USA.

Baron, J. S., M. D. Hartman, L. E. Band, and R. L. Lammers. 1998. Sensitivity of high elevation Rocky Mountain watersheds to climate change. Proceedings of the Fifth National Watershed Coalition Annual Meeting, May 1997, Reno, Nevada, USA, in press.

Beebe, R. C. 1974. Large scale irrigation and severe storm enhancement. Pages 392-395 in Symposium on Atmospheric Diffusion and Air Pollution. American Meteorological Society, Santa Barbara, California, USA.

Beven, K. J., and M. J. Kirkby. 1979. A physically-based, variable contributing area model of basin hydrology. Hydrological Sciences Bulletin (Bulletin des Sciences Hydrologiques) 24:43-69. 
Bowman, W. D., T. A. Theodose, J. C. Schardt, and R. T. Conant. 1993. Constraints of nutrient availability on primary production in two alpine communities. Ecology 74: 2085-2097.

Burke, I. C., T. G. F. Kittel, W. K. Lauenroth, P. Snook, C. M. Yonker, and W. J. Parton. 1991. Regional analysis of the central great plains: sensitivity to climate variability. BioScience 41:685-692.

Chase, T. N., R. A. Pielke, T. G. F. Kittel, and J. S. Baron. 1998. Impacts on Rocky Mountain weather and climate due to land use changes in the adjacent Great Plains. Journal of Geophysical Research, in press.

Chase, T. N., R. A. Pielke, T. G. F. Kittel, R. Nemani, and S W. Running. 1996. The sensitivity of a general circulation model to large scale vegetation change. Journal of Geophysical Research 101:7393-7048.

Copeland, J. H., R. A. Pielke, and T. G. F. Kittel. 1996 Potential climatic impacts of vegetation change: a regional modeling study. Journal of Geophysical Research 101: 7409-7418.

Colorado Climate Data. 1992. Monthly climate records. Colorado Climate Center, Department of Atmospheric Sciences, Colorado State University, Fort Collins, Colorado, USA.

Creed, I. F., L. E. Band, N. W. Foster, I. K. Morrison, J. A. Nicolson, R. S. Semkin, and D. S. Jeffries. 1996. Regulation of nitrate-N release from temperate forests: a test of the $\mathrm{N}$ flushing hypothesis. Water Resources Research 32: 3337-3354.

Dennehy, K. F., D. W. Litke, C. M. Tate, and J. S. Heiny. 1993. South Platte River Basin-Colorado, Nebraska, and Wyoming. Water Resources Bulletin 29:647-683.

Dickinson, R. E., A. Henderson-Sellers, P. J. Kennedy, and M. F. Wilson. 1986. Biosphere-atmosphere transfer scheme (BATS) for the NCAR community climate model. NCAR/TN-275 + STR Technical Note. National Center for Atmospheric Research, Boulder, Colorado, USA

Eidenshink, J. C. 1992. The 1990 conterminous U.S AVHRR data set. Photogrammetric Engineering and Remote Sensing 58:809-813.

Goudie, A. 1990. The human impact on the natural environment. Third edition. MIT Press, Cambridge, Massachusetts, USA.

Hansen, W. R., J. Chronic, and J. Matelock. 1978. Climatography of the Front Range Urban Corridor and vicinity. Colorado Geological Survey Professional Paper Number 1019. U.S. Government Printing Office, Washington, D.C., USA.

Hunt, E. R., Jr., S. C. Piper, R. Nemani, C. D. Keeling, R. D. Otto, and S. W. Running. 1996. Global net carbon exchange and intra-annual atmospheric $\mathrm{CO}_{2}$ concentrations predicted by an ecosystem process model and three-dimensional atmospheric transport model. Global Biogeochemical Cycles 10:431-456.

Karl, T. R., P. D. Jones, R. W. Knight, G. Kukla, N. Plummer V. Razuvayev, K. P. Gallo, J. Lindseay, R. J. Charlson, and T. D. Peterson. 1993. A new perspective on global warming. Bulletin of the American Meteorological Society 74: 1007-1023.

Kittel, T. G. F., N. A. Rosenbloom, T. H. Painter, D. S. Schimel, and VEMAP Modeling Participants. 1995. The VEMAP integrated database for modeling U.S. ecosystem/ vegetation sensitivity to climate change. Journal of Biogeography 22:857-862.

Küchler, A. W. 1975. Potential natural vegetation of the United States. Second edition. Map 1:3, 168000. American Geographical Society, New York, New York, USA

Lammers, R. B. 1998. Extending hydro-ecological simulation models from local to regional scales. Dissertation. De- partment of Geography, University of Toronto, Toronto, Canada.

Lammers, R. B., L. E. Band, and C. L. Tague. 1997. Scaling behavior of watershed processes. Pages 295-317 in P. R. van Gardingen, G. M. Foody, and P. J. Curran, editors. Scaling-up from cell to landscape. Cambridge University Press, London, UK.

Lapitan, R. L., and W. J. Parton. 1996. Seasonal variabilities in the distribution of the microclimatic factors and evapotranspiration in a shortgrass steppe. Agricultural and Forest Meteorology 79:113-130.

Lauenroth, W. K., and O. E. Sala. 1992. Long-term forage production of North American short-grass steppe. Ecological Applications 2:397-403.

Lee, T. J. 1992. The impact of vegetation on the atmospheric boundary layer and convective storms. Atmospheric Science Paper Number 509. Colorado State University, Fort Collins, Colorado, USA

Likens, G. E., and F. H. Borman. 1995. Biogeochemistry of a forested ecosystem. Second edition. Springer-Verlag, New York, New York, USA.

Loveland, T. R., J. W. Merchant, D. O. Ohlen, and J. F. Brown. 1991. Development of a land-cover characteristics database for the conterminous U.S. Photogrammetric Engineering and Remote Sensing 57:1453-1463.

Lubchenko, J., et al. 1991. The Sustainable Biosphere Initiative: an ecological research agenda. Ecology 72:371412.

Lytle, D. J. 1993. Digital soils databases for the United States. Pages 386-391 in M. F. Goodchild, B. O. Parks, and L. T. Steyaert, editors. Environmental modeling with GIS. Oxford University Press, London, UK.

McDowell, P. F., T. Webb III, and P. J. Bartlein. 1990. Longterm environmental change. Pages 143-162 in B. L. Turner II, W. C. Clark, R. W. Kates, J. F. Richards, J. T. Mathews, and W. B. Meyer. 1990. The earth as transformed by human action: global and regional changes in the biosphere over the past 300 years. Cambridge University Press, New York, New York, USA.

Meher-Homji, M. V. 1991. Probable impact of deforestation on hydrological processes. Climatic Change 19:163-173.

Merchant, J. W., L. Yang, and W. Yang. 1996. Validation of continental-scale land cover data bases developed from AVHRR data. In W. T. Pecora Memorial Symposium on Remote Sensing (12th): Proceedings. Sioux Falls, South Dakota, August 1993. American Society for Photogrammetry and Remote Sensing, Bethesda, Maryland, USA.

Metherell, A. K. 1992. Simulation of soil organic matter dynamics and nutrient cycling in agroecosystems. Dissertation. Colorado State University, Fort Collins, Colorado, USA.

Metherell, A. K., W. J. Parton, C. A. Cambardella, G. A. Peterson, L. A. Harding, and C. V. Cole. 1993. Simulation of organic matter dynamics in dryland wheat-fallow cropping systems. Pages 259-270 in R. Lal, J. Kimble, E. Levine, and B. A. Stewart, editors. Soil management and greenhouse effect. Lewis, Boca Raton, Florida, USA.

Morse, S. R., and F. A. Bazzaz. 1994. Elevated $\mathrm{CO}_{2}$ and temperature alter recruitment and size hierarchies in $\mathrm{C}_{3}$ and $\mathrm{C}_{4}$ annuals. Ecology 75:966-975.

Nash, L. L., and P. Gleick. 1993. The Colorado River Basin and climatic change. Report for the Environmental Protection Agency. EPA 230-R-93-009. Pacific Institute for Studies in Development, Environment, and Security, Oakland, California, USA.

NRC (National Research Council). 1992. Water transfers in the West: efficiency, equity, and the environment. National Academy Press, Washington, D.C., USA.

Ojima, D. S., W. J. Parton, D. S. Schimel, and J. M. O. Scurlack. 1993. Modeling the effects of climatic and $\mathrm{CO}_{2}$ 
changes on grassland storage of soil C. Water Air and Soil Pollution 70:643-657.

Parton, W. J., D. S. Schimel, C. V. Cole, and D. S. Ojima. 1987. Analysis of factors controlling soil organic matter levels in Great Plains grasslands. Soil Science Society of America Journal 51:1173-1179.

Peet, R. K. 1989. Forest of the Rocky Mountains. Pages 64101 in M. G. Barbour and W. D. Billings, editors. North American terrestrial vegetation. Cambridge University Press, New York, New York, USA.

Pielke, R. A., W. R. Cotton, R. L. Walko, C. J. Tremback, M. E. Nicholls, M. D. Moran, D. A. Wesley, T. J. Lee, and J. H. Copeland. 1992. A comprehensive meteorological modeling system-RAMS. Meteorology and Atmospheric Physics 49:69-91.

Pielke, R. A., T. J. Lee, J. H. Copeland, J. L. Eastman, C. L. Ziegler, and C. A. Finley. 1997. Use of USGS-provided data to improve weather and climate simulations. Ecological Applications 7:3-21.

Polley, H. W., H. B. Johnson, H. S. Mayeux, and C. R. Tischler. 1996. Are some of the recent changes in grassland communities a response to rising $\mathrm{CO}_{2}$ concentrations? Pages 177-196 in C. Körner and F. A. Bazzaz, editors. Carbon dioxide, populations, and communities. Academic Press, New York, New York, USA.

Rabin, R. M., and D. W. Martin. 1996. Satellite observations of shallow cumulus coverage over the central United States: an exploration of land use impact on cloud cover. Journal of Geophysical Research 101:7149-7155.

Rango, A. 1995. Effects of climate change on water supplies in mountainous snowmelt regions. World Resource Review 7:315-325.

Running, S. W., and J. C. Coughlan. 1988. A general model of forest ecosystem processes for regional applications. I. Hydrologic balance, canopy gas exchange, and primary production processes. Ecological Modeling 42:125-154.

Running, S. W., and R. R. Nemani. 1991. Regional hydrologic and carbon balance response of forests resulting from potential climate change. Climatic Change 19:349-368.

Running, S. W., R. R. Nemani, D. L. Peterson, L. E. Band, D. F. Potts, L. L. Pierce, and M. A. Spanner. 1989. Mapping regional forest evapotranspiration and photosynthesis by coupling satellite data with ecosystem simulation. Ecology 70:1090-1101.

Sala, O. E., W. J. Parton, L. A. Joyce, and W. K. Lauenroth 1988. Primary production of the central grassland region of the United States. Ecology 69:40-45.

Sanford, R. L., W. J. Parton, D. S. Ojima, and D. J. Lodge. 1991. Hurricane effects on soil organic matter dynamics and forest production in the Luquillo Experimental Forest, Puerto Rico: results of simulation modeling. BioTropica 23:364-372.

Schimel, D. S., W. J. Parton, T. G. F. Kittel, D. S. Ojima, and C. V. Cole. 1990. Grassland biogeochemistry: links to atmospheric processes. Climatic Change 17:13-25.

Schindler, D. W. 1997. Widespread effects of climatic warming on freshwater ecosystems in North America. Hydrological Processes 11:1043-1067.

Segal, M., W. E. Schreiber, G. Kallos, J. R. Garratt, A. Rodi, J. Weaver, and R. A. Pielke. 1989. The impact of crop areas in northeast Colorado on midsummer mesoscale thermal circulations. Monthly Weather Review 117:809-825.

Seth, A., and F. Giorgi. 1996. Three-dimensional model study of organized mesoscale circulations induced by vegetation. Journal of Geophysical Research 101:7371-7391.

Shanahan, J. F. 1982. Tiller age, survival, and morphology relative to grain yield in winter wheat. Dissertation. Colorado State University, Fort Collins, Colorado, USA.

Shortgrass Steppe Long-Term Ecological Research. 1996.
Climate data collected on-site at Nunn, Colorado. Colorado State University, Fort Collins, Colorado, USA.

Shukla, J., and Y. Mintz. 1982. Influence of land surface evapotranspiration on the Earth's climate. Science 215: 1498-1501.

Shukla, J., C. Nobre, and P. Sellers. 1990. Amazon deforestation and climatic change. Science 247:1322-1325.

Sims, P. L. 1989. Grasslands. Pages 265-286 in M. C. Barbour and W. D. Billings, editors. North American terrestrial vegetation. Cambridge University Press, New York, New York, USA.

Stegner, W. 1987. The American West as living space. University of Michigan Press, Ann Arbor, Michigan, USA.

Steyaert, L. T., T. R. Loveland, and W. J. Parton. 1997. Land cover characterization and land surface parameterization research. Ecological Applications 7:1-3.

Stohlgren, T. J., and R. R. Bachand. 1997. Lodgepole pine (Pinus contorta) ecotones in Rocky Mountain National Park, USA. Ecology 78:632-641.

Stohlgren, T. J., T. N. Chase, R. A. Pielke, T. G. F. Kittel, and J. S. Baron. 1998. Evidence that local land use practices influence regional climate and vegetation patterns in adjacent natural areas. Global Change Biology $\mathbf{4}$, in press.

Thornton, P. E., S. W. Running, and M. A. White. 1997. Generating surfaces of daily meteorological variables over large regions of complex terrain. Journal of Hydrology 190: 214-251.

Turner, B. L. II, W. C. Clark, R. W. Kates, J. F. Richards, J. T. Mathews, and W. B. Meyer. 1990. The earth as transformed by human action: global and regional changes in the biosphere over the past 300 years. Cambridge University Press, New York, New York, USA.

VEMAP Members. 1995. Vegetation/ecosystem modeling and analysis project: comparing biogeography and biogeochemistry models in a continental-scale study of terrestrial ecosystem responses to climate change and $\mathrm{CO}_{2}$ doubling. Global Biogeochemical Cycles 9:407-437.

Walker, M. D., P. J. Webber, E. H. Arnold, and D. Ebert-May. 1994. Effects of interannual climate variation on aboveground phytomass in alpine vegetation. Ecology 75:393408.

Watson, R. T., M. C. Zinyowera, and R. H. Moss, editors. Climate change 1996. Impacts, adaptations and mitigation of climate change: scientific technical analyses. Contribution of Working Group II to the Second Assessment Report of the Intergovernmental Panel on Climate Change. Cambridge University Press, New York, New York, USA.

Webber, P. J., and D. E. May. 1977. The magnitude and distribution of belowground plant structures in the alpine tundra of Niwot Ridge, Colorado. Arctic and Alpine Research 9:157-174.

Williams, M. W., M. Losleben, N. Caine, and D. Greenland. 1996. Changes in climate and hydrolochemical responses in a high-elevation catchment in the Rocky Mountains, USA. Limnology and Oceanography 41:939-946.

Zelt, R. B., J. F. Brown, and M. S. Kelley. 1995. Validation of national land-cover characteristics data for regional water quality assessment. Geocarto International 10:69-80.

Zhang, H., A. Henderson-Sellers, and K. McGuffie. 1996. Impacts of tropical deforestation. Part I: Process analysis of local climate change. Journal of Climate 9:1497-1517.

Zhu, Z., D. O. Ohlen, R. L. Czaplewski, and R. E. Burgan. 1996. Alternative method to validate the seasonal land cover regions of the conterminous United States. Pages 409418 in Spatial Accuracy Assessment in Natural Resources and Environmental Science: Second International Symposium. General Technical Report RM-GTR-277. Rocky Mountain Forest and Range Experiment Station, Fort Collins, Colorado, USA. 